\title{
AICEI PROCEEDINGS
}

Ilijana Petrovska

Ljupka Naumovska

Milica Todorovska

\section{Financial Institutions' Marketing Communication during economic downturn and implications on the Corporate Image}

\begin{abstract}
The world economic crisis has necessitated finding ways for survival in the most pessimistic scenarios or just cutting costs in the best situations. US Banks suffered the most from the crisis. Banks in Macedonia are not feeling the same effects. The world financial crisis didn't jeopardize the stability and liquidity of the Macedonian financial system because of the strong deposit base, banks' low debt and the prudent regulatory system, which maintained a healthy banking portfolio. However, the Financial Institutions in Macedonia are already feeling the consequences of the global financial crisis.

The Advertising sectors of the global financial institutions are showing lower marketing budgets, but importantly they have not been cut completely. Banks are working on increasing their deposits through their corporate image communications. This means that the financial institutions' advertising should continue in order to keep and strengthen banks' corporate image and should stress the stability of the banks.

This paper presents the advertising activity of the financial institutions during the current world economic crisis and the consequent marketing communication budget reallocation. The effects of the banks' marketing communication during the crisis is shown with data on the banks' customer and market share and on the banks' corporate image perception.
\end{abstract}

Keywords: advertising, financial institution advertising, crises, corporate image, savings, loans and marketing communications. 


\section{Introduction}

We are witnessing the one of the largest, the strongest and the longest financial crisis in the World. It is nothing new how marketing communications has influenced in the previous crises, but current crisis has its own specifics, as also the marketing communication tactics has been developed and reach certain level of interest. From the third side, also the financial services have its own specifics, which influence on the marketing communication strategy development and implementation.

In this paper we research how the current crisis is influencing on the financial market development and sales in Macedonia and in the region. The most important question elaborated in this research, is how important is the marketing communication during an economic downturn and the influence on the further business growth.

The research is conducted through direct interviews with several financial institutions in Macedonia and in the region. All of them have developed unique and specific marketing communication strategy, in order to match their business goals and survive during the current crisis. Each strategy implementation is generating appropriate results and sales implications as a conclusion.

\section{History of World crisis and advertising implications}

According to the Wikipedia Dictionary (May, 2009) there is no commonly accepted definition of a global recession. However, Internationally Monetary Fund (IMF) regards periods when global growth is less than $3 \%$ to be global recessions. The IMF estimates that global recessions seem to occur over a cycle lasting between 8 and 10 years. During recessions, many macroeconomic indicators vary in a similar way. Production as measured by Gross Domestic Product (GDP), employment, investment spending, capacity utilization, household incomes and business profits all fall during recessions. Governments usually respond to recessions by adopting expansionary macroeconomic policies, such as increasing money supply, increasing government spending and decreasing taxation.

The current market jitters are centered on disturbances in the world's credit markets. Worries about the viability of sub-prime mortgage lending have spread around the financial system, and the central banks have been forced to pump in billions of dollars to oil the wheels of lending. But what happened in previous financial crises, and what are the lessons for today?

There have been a growing number of financial crises in the world. According to the International Monetary Fund (IMF) this is a short list of some major financial crises since 20th century (Wikipedia dictionary, May 2009):

- 1910 - Shanghai rubber stock market crisis

- 1930s - The Great Depression - the largest and most important economic depression in the 20th century 
- 1973 - oil crisis - oil prices soared, causing the 1973-1974 stock market crash

- 1980s - Latin American debt crisis - beginning in Mexico

- 1987 - Black Monday (1987) - the largest one-day percentage decline in stock market history

- 1989-91 - United States Savings \& Loan crisis

- 1990s - Japanese asset price bubble collapsed

- 1992-93 - Black Wednesday - speculative attacks on currencies in the European Exchange Rate Mechanism

- 1994-95 - economic crisis in Mexico - speculative attack and default on Mexican debt

- 1997-98 -Asian Financial Crisis - devaluations and banking crises across Asia

- 2007-09 - The American financial crisis of 2007-2009 helped create the global financial crisis of 2008-2009, thus creating the late 2000s recession

Among the key lessons of previous major financial crises are (Schifferes, 2007):

- Globalization has increased the frequency and spread of financial crises, but not necessarily their severity

- Early intervention by central banks is more effective in limiting their spread than later moves

- It is difficult to tell at the time whether a financial crisis will have broader economic consequences

- Regulators often cannot keep up with the pace of financial innovation that may trigger a crisis.

Those who don't know history are doomed to repeat it. As DiMassimo has founded (2001) in an article written by E.B. Weiss in 1942, as if it could have been written today, Weiss offers the following thoughts on advertising in wartime:

- The advertising must be distinctive, to be noticed at all.

- It must be timely. (The anxious are tuned to every scrap of news.)

- It must be brand-building. (Ignore what others may say about gaining readership by hiding your logo.)

- It must create conversation, to amplify your small budget. 
- It must stir emotion.

It should consider the "saving grace" of humor. (Because people crave relief from the grim tidings of the nightly newscast.) It must be believable. The trend toward branding. The trend toward targeting, measurement and data-keeping--the most important factors affecting marketing communications today.

According to Pacek \& Thorniley (2004) some companies argue that crises turn out to be positive for their operations, making them lean and mean, and providing opportunity to get rid of average and bad performers.

So what to do in times of recession, when you need every penny to sustain earnings? Stop advertising? If you stop advertising a brand that is still in its introductory phase, you will probably kill it forever (Ogilvy, 1983).
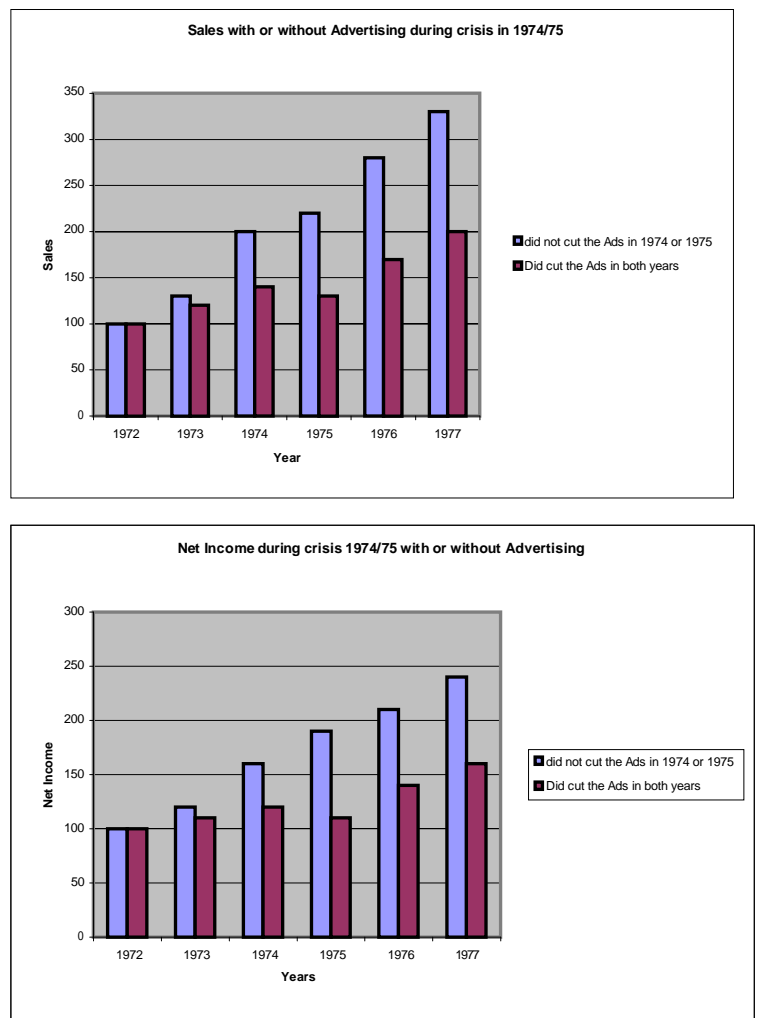

Source: From American Business Press from the Book "Ogilvy on advertising" by Ogilvy D (1985), First Vintage Books Edition. P. 171 
Studies of the last six recessions have demonstrated that companies that do not cut back their advertising budgets achieve greater increases in profit than companies that do cut back.

\section{Implications of the World Crisis on the Macedonian market}

The financial crisis of 2007-2009 began in July 2007 (Wikipedia, May 2009) when a loss of confidence by investors in the value of securitized mortgages in the United States resulted in a liquidity crisis that prompted a substantial injection of capital into financial markets. In September 2008, the crisis deepened, as stock markets worldwide crashed and entered a period of high volatility, and a considerable number of banks, mortgage lenders and insurance companies failed in the following weeks.

It was widely argued that an international crisis required an international solution. In

The global economic and financial crisis began to show its effects on Macedonian market at the beginning of the last quarter in 2008. The Macedonian financial market in general is marked with strong dominance of banks against leasing, savings and insurance companies and therefore, the financial crisis was reflected at the banking segment at the beginning, sourcing decline in financing volume and banking products reallocation. The financial institution reacted on the crisis by changing their business model, mainly from aggressive and competitive market approach to rigid and cautious. Hence, the financial institutions' marketing strategies and plans are adjusted accordingly.

Although the effects on the domestic output were felt in the last quarter of 2008, the potential slowdown of the economic growth in the following period could be significantly larger. Such expectations rest on the assessments for reduced exports, but also slowdown of the total domestic demand in conditions of deteriorated perceptions about the future economic flows and income, as well as the significantly harder access to external financing and more rigorous terms of lending. The world crisis and its repercussions on the domestic economy already affect the sources of funding of the domestic banks and their perceptions about the future risk, which causes a decline in the credit supply (NBRM, January 2009).

The negative implications of the financial crisis were recognized in two segments:

- Real sector and

- Financial market. 
Real sector implications from the financials crisis can be explained through inflation and industrial output deviations.

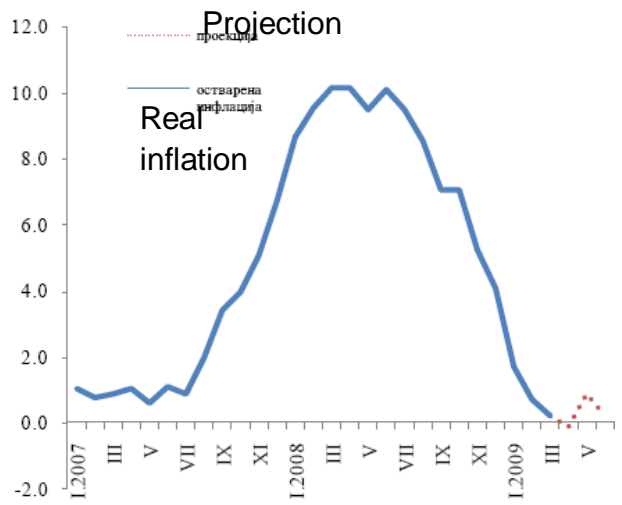

Source: Inflation, yearly changes in \%, State statistical bureau of R. Macedonia, NBRM, Quarterly Report January 2009

Alongside with the slowdown of Macedonian economy, a remarkable decrease of inflation rate has aroused. This decrement continued in the first quarter of 2009 , when the rate went down to $1 \%$, compared with $5,4 \%$ in last quarter of 2008 and $9,9 \%$ in the second quarter of 2008. (NBRM, Quarterly report April 2009).

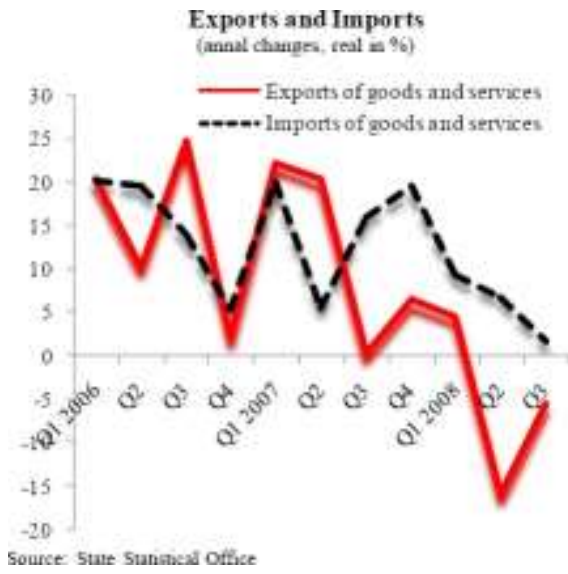

The real annual GDP growth projected for the first quarter of 2009 equals roughly $1 \%$. Besides the developments in the industry, which are the major 
risk to the real growth to register lower rate than projected, the tendencies in the trade (sector which contributed the most to the GDP growth in 2008) are also significant. (NBRM, Monthly report February 2009).

\section{Financial market}

The banking sector in such an environment was aimed at boosting the domestic saving in the form of deposits, as the main source of financing banks' credit activity. In conditions of rising competition on the deposit market, banks' interest rate policy was aimed at continuous increase in deposit interest rates, also in the third quarter of the year. Banks' perceptions regarding the potential deterioration of the performances of the economic entities, together with the narrowing of the deposit potential and reduction of the banks' net foreign assets, in conditions of global liquidity shortage and more gigolos terms of borrowing from external sources, acted toward further deceleration of the credit growth. The partial tightening of the lending terms in the third quarter, especially for extending consumer credits and the perceptions for continuation of such a trend in the forthcoming period, are expected to influence the households' decisions for spending, especially in conditions when the effects from the other sources of financing personal consumption (wages, private transfers) are accompanied by high level of uncertainty. (NBRM, Quarterly Report January 2009)

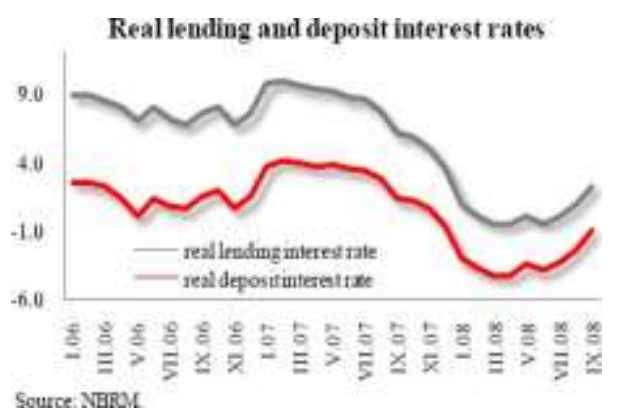

Constant rise in the interest rates of the banks was also registered in the Euro area countries 26 , with continuation of this trend in the forthcoming period being expected. Such a policy of the European banks results from the expectations for the future economic activities of the companies, the restricted possibilities for access to the finances, as well as the enhanced risks with the economic agents. 
In order to prevent future worsening of the economy and to maintain the quality of the banking portfolio, Central Bank of Macedonia brought new set of measures in frames of monetary policy (NBRM, press release Skopje, 25 December 2008):

1. Decision on a compulsory deposit with the National Bank of the Republic of Macedonia.

2. Decision on liquidity risk management.

3. Decision on foreign currency deposits with the National Bank of the Republic of Macedonia

4. Decision on the exposure limits

5. Decision on managing interest rate risk in the banking book

6. Decision on determining the types of securities that the authorized banks may purchase and sell

7. Decision on reserve requirements

8. Others.

These restrictions influenced on the financing volume of the banks in Macedonia and hence on their marketing communication activities.

Evidently there is strong link among the crisis, financial product reallocation and advertising activities related. More precisely, the financial crisis evoked the following strategic changes in terms of marketing communications and product development:

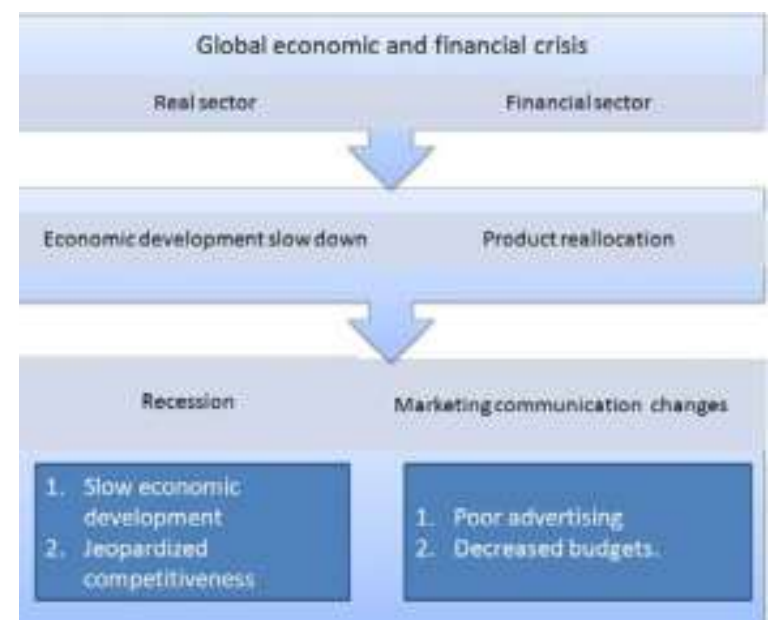


Picture 1: The link between the global crisis, company's business model and marketing communication strategy

The global crisis as mentioned above, already caused significant long term implications on the real and financial segment. Hence, the companies are facing necessity of readjustments of the business models in accordance with the external changes due to the crisis. The financial institutions are bearing the most "heavy" burden, as perceived as carriers of the crisis, so that the image of stability and trust is jeopardized. In order to struggle or even maintain the position on the market, they need to reallocate their products, to review brand architecture and adopt marketing budgets. These changes are the greatest challenge of the financial institutions during a financial downturn.

\section{Macedonian market financial services diversification}

The segmentation of the financial market in terms of financial products is applicable for the Macedonian market and the regional countries. The chart shows the most frequently used financial services for banking and leasing customers from:
1. Austria
2. Slovenia
3. Croatia
4. Bosnia and Herzegovina
5. Serbia
6. Montenegro
7. Macedonia 


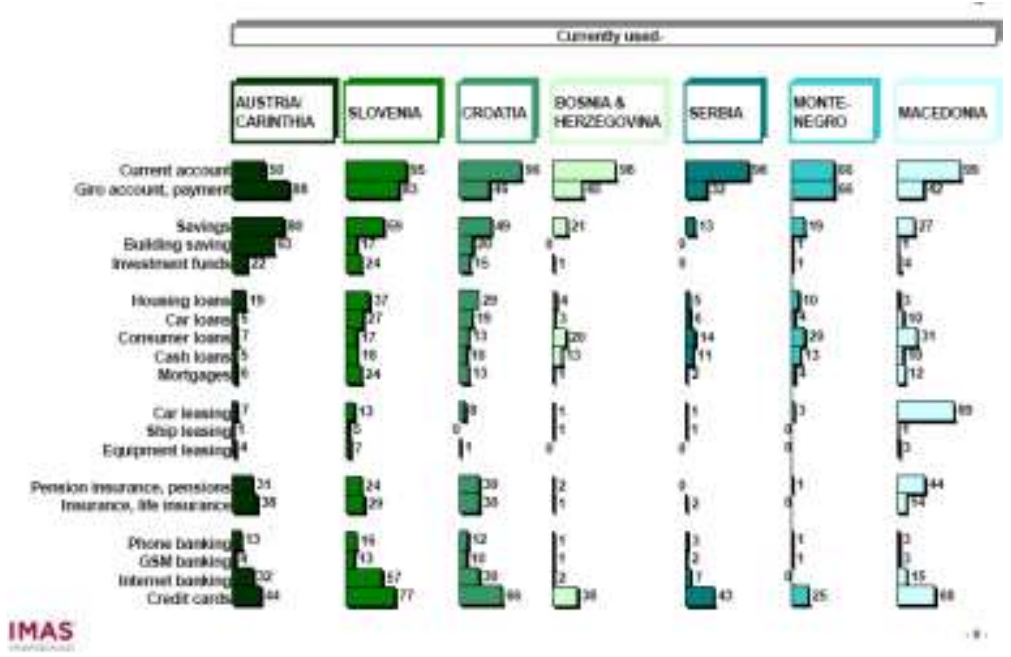

Source: Market research performed by IMAS International; Client: Hypo Bank International, January \& February 2009

Researched quote is 500 banking and leasing customers from each of the above-mentioned countries. According to the above-mentioned research, Macedonian customers are showing interest for short-term financial services such as current account, credit cards and consumer loans. Obviously they are sustaining from long-term investments. On contrary Austrian customers are using gyro accounts, savings and life insurance at most. Serbia and Montenegro customers are showing similar behavior as Macedonian customers.

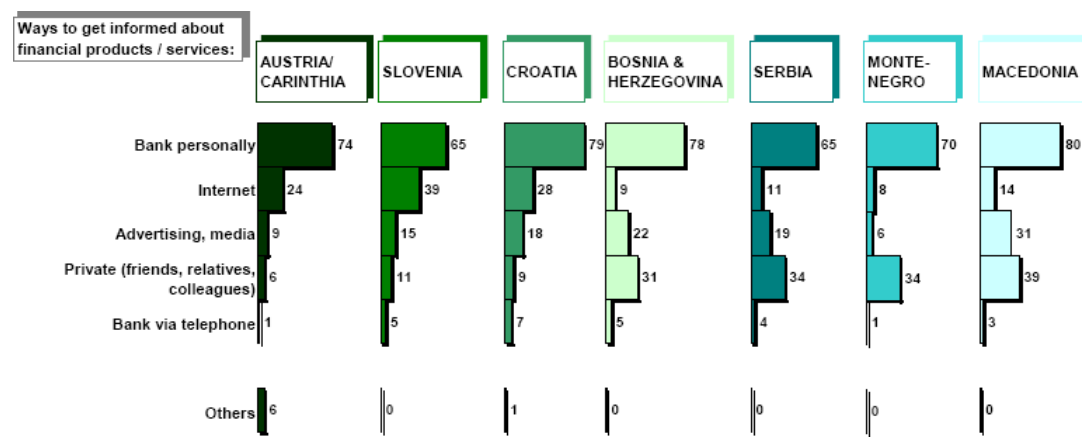


Source: Market research performed by IMAS International; Client: Hypo Bank International, January \& February 2009

The chart shows the perceptiveness of Macedonian and regional financial service customers for getting information about specific financial service. Clearly, the banks staff and word of mouth plays a great role for Macedonian customers. At these directions, the trainings and staff attitude, particularly the front desk employees should be recognized as an important component of the promotional activities of the banking or leasing institutions.

\section{Analyses of the current financial institutions' Advertising}

News about the credit crisis just seems to go from bad to worse, with no end in sight. Indeed, the past months have felt like financial Armageddon. So how should these institutions be communicating? What should they be saying to their customers? What messages are resonating with people and what ones are not? Though many of our nation's banks are doing just fine, it is hardly business as usual for them in terms of communications.

History tells us that, absent communication, rumor, speculation, and innuendo rush in to fill the void, leaving in their wake mounting fear and anxiety among company stakeholders and the public at large.

Last June a Gallup Poll showed that consumer confidence in banking had fallen near its lowest level - $32 \%$ - since the firm began asking this question in 1979. This month another Gallup Poll found that among affluent Americans - those with $\$ 100,000$ or more of investable assets - confidence in banks had fallen below $25 \%$.

So what would be "all or nothing" communication approach versus a "communicating through good times and bad" approach that has been the foundation of public relations best practices since the days of Teddy Roosevelt.

As public relations professional Iverson (2008) has worked in the financial services industry for well over 20 years, he has often been asked for guidance from corporate leaders in times of crisis. To be clear, there are many levels and kinds of crises. But let's face it: All banks are under duress right now in the court of public opinion. With this as their backdrop, what can banks do? Iverson would say: Break the silence. 
Silence is a powerful and destructive form of communication. So say something, do something. And in due time, the public will reward you for your good corporate citizenship, and for your courage to lead.

Public Relation (PR) is another part of the marketing mix, which is very useful in times of crises. For example (Janine Gordon):

- Think PR when times are bad or in the face of crisis. In the aftermath of 9/11, Bankrate.com, the leading aggregator of personal finance information on the Web, wanted to reassure advertisers that its reach and effectiveness were unaffected by the attacks. The Internet site quickly mounted a fullbore effort, including one-on-one outreach to each Bankrate.com advertiser. The result: not one cancelled scheduled advertising.

- When marketing dollars are limited, PR delivers more bang for the buck. A strong PR campaign generally costs a fraction of what a high-impact advertising effort would require. Consequently, when the marketing budget is tight, PR is the more productive use of funds.

- Nothing enhances a damaged reputation like credible PR. To improve a tarnished image, a company must first fix the problem. But once wrongs have been righted, nothing enhances a damaged reputation like a credible PR campaign.

\section{Macedonian Banking market}

As it is already mentioned, the World crisis influenced over the Macedonian economy and the Macedonian banking sector. After the first signs were noticed set of measures were undertaken by the Commercial Banks in Macedonia. The measurements that were undertaken from the National Bank of Macedonia were increasing the interest rate of the treasury bills and introducing compulsory deposit. The introduced compulsory deposit means that the bank shall be obliged to allocate a compulsory deposit if, at the end of the month, it registers growth in the household credits higher than the allowed growth rates compared to calculation base.

The changes that were done at the beginning were more focused on strengthening the credit criteria under which the loans were approved and also slight increase of the interest rates. For maintaining the proper liquidity, the banks started also with increasing of the deposits interest rates and offering new types of deposits sometimes with special offers for limited time period. It was noticed that the strengthening of the credit criteria was much stronger for the corporate loans compared to the retail 
loans. At the same time the customers' interest for corporate loans is not decreased compared with the previous period, and the customers' interest for retail loans is considerably decreased.

During the next months all the banks continued with strengthening the credit criteria and increasing the interest rates for lending products and at the same time increasing the interest rates for deposits. The movement of the interest rates in local currency is depending on the movements of the treasury bills' interest rate offered by the Central bank on auction. According to the latest Central Bank's auction held on $20^{\text {th }}$ of May 2009 the annual interest rate is $9 \%$ (for comparison the annual interest rate of the treasury bills in May 2008 was $6.50 \%$ ). The movement of the interest rates in foreign currency is depending on the movements of the EURIBOR interest rate. The current annual interest rate is $1.6 \%$ compared to the annual interest rate from last year in May 5\% (Euribor-rates.eu, May 2009). The banks currently are in a very delicate situation. In order to attract more deposits and to be more competitive on the market they are increasing the interest rates above the interest rates of the treasury bills and the EURIBOR rate, contributing negative spread for the banks.

The Sales before and during the crisis, is showing different results according different product type. According to the survey for credit activity, undertaken from the Central Bank of Macedonia on periodical basis, following are few charts:

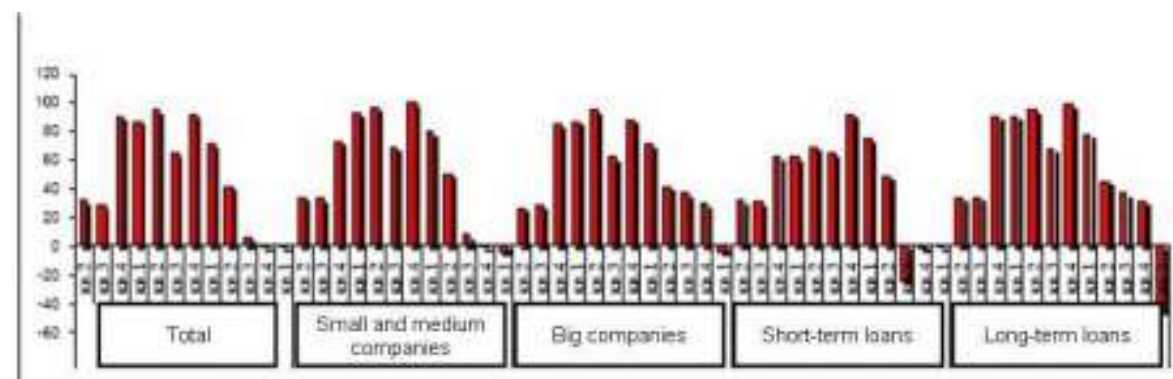

Source: Corporate loans demand, NBRM, Survey for credit activity, May 2009

According to this chart and the results of the survey for the changes in the demand for corporate loans we can see that there is no considerable decrease in the demand and the main reason stated from the banks is the need for financing the companies. Also it is noticed that the demand for 
short-term loans is not decreased and there is slightly higher decrease in the demand for long-term loans.

Also according to the following chart we can see the considerable influence of the monetary policy in changing the interest rates of the corporate loans.

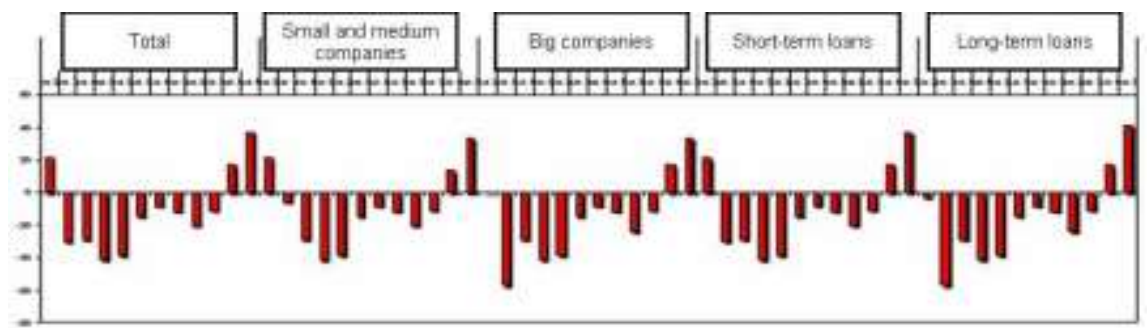

Source: Influence of the monetary policy over the corporate loans' interest rates, NBRM, Survey for credit activity, May 2009

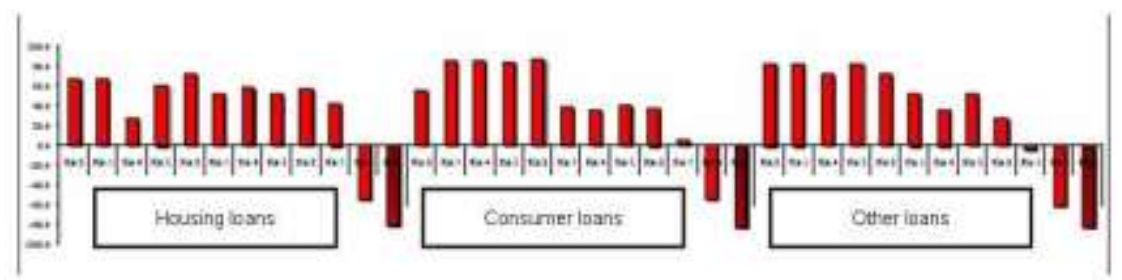

Source: Retail loans demand, NBRM, Survey for credit activity, May 2009

According to this chart and the results of the survey for the changes in the demand for retail loans we can see that there is considerable decrease in the demand. Almost all banks have stated that the demand in the retail loans is decreased, especially noticed in consumer and housing loans, and as a main reason for the decreased interest for this type of loans are the increased expenses for satisfying daily needs of the consumers.

In the next chart we can see the movements presented in percentages in the total sales (including all Banks in Macedonia) during 2007, 2008 and beginning of 2009. It is obvious that in 2007 there is a continual increase in the household credit sales moving between $3 \%$ and $5 \%$. 


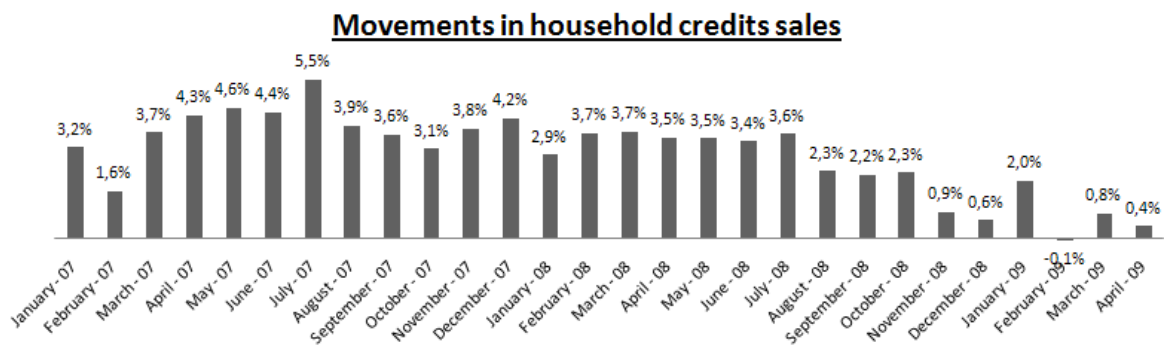

Source: Movements in household credit sales, Internal report of Stopanska Banka AD - Skopje, May 2009

In 2008 the increase is more constant mainly around 3\% in the first half of the year and increase with lower percentages in the second half of the year. The start of this year, 2009 is with $2 \%$ increase, but the reason is not the real increase. At the beginning of this year was implemented new methodology of measuring the sales of the loans. In 2009 is noticed in February negative movement and in March and April is noticed very low increase.

According to the following chart we can see the considerable influence of the monetary policy in changing the interest rates of the retail loans.

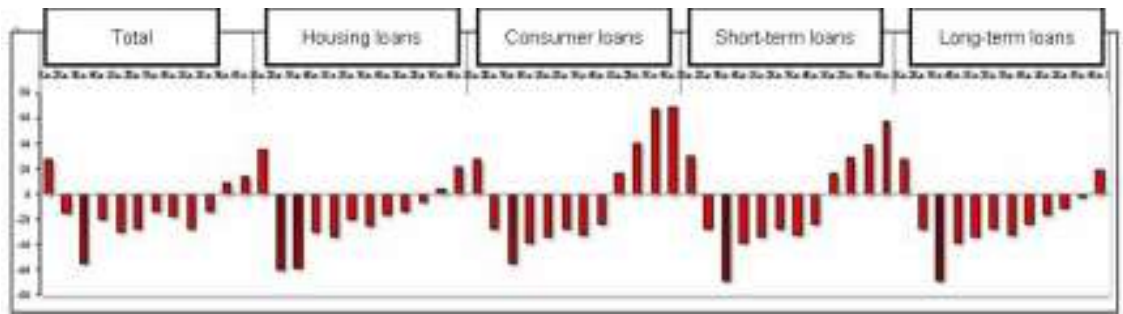

Source: Influence of the monetary policy over the retail loans' interest rates, NBRM, Survey for credit activity, May 2009

The deposits are very important segment for the Banks in order to maintain the proper liquidity, especially in this period of time. All Banks compete for bigger market share at this moment by offering special offers to the clients with attractive interest rates. 


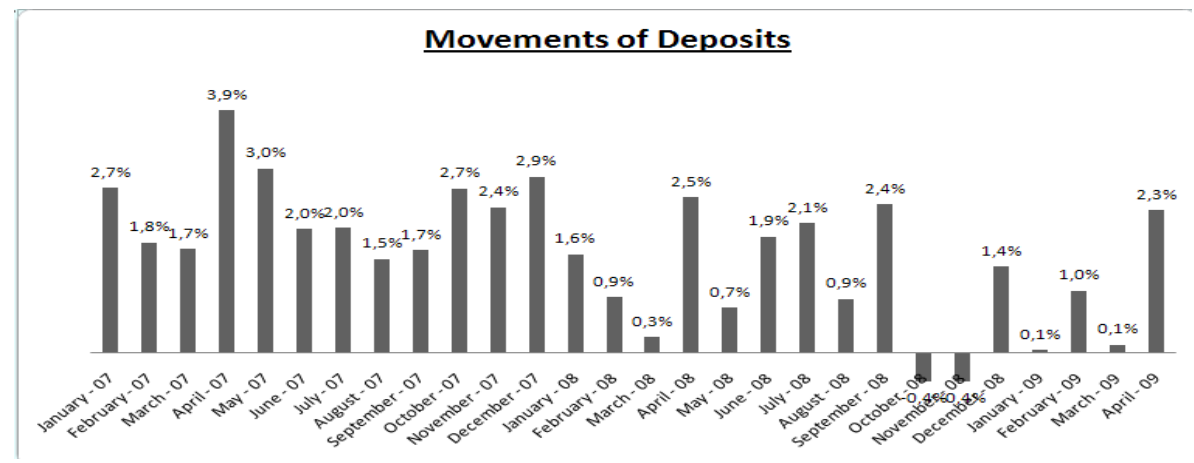

Source: Movements of deposits, Internal report of Stopanska Banka AD - Skopje, May 2009

As we can see from the chart above there is a highest growth during 2007 and during 2008 there is a lower increase in the deposits' base. Because of the unstable situation it is noticed negative rate in October and November 2008, and during the months in 2009 it is noticed growth, which is not very high and constant.

As we can see in the next chart during 2007 the interest of the clients for deposits in local currency is constantly growing and in the months November and December 2007 the participation of the deposits in local currency is the highest $-46 \%$. During 2008 there are not any significant movements. But at the end of 2008 and beginning of 2009 again the clients are switching the deposits from local currency to deposits in foreign currency because of the client's fear of denar devaluation.

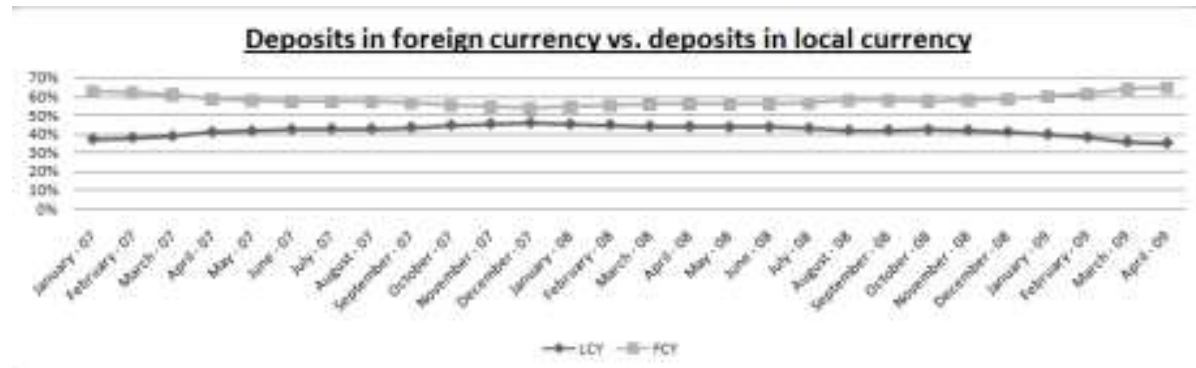

Source: FCY deposits vs. LCY deposits, Internal report of Stopanska Banka AD - Skopje, May 2009 


\section{Banks' advertising activities}

As we already know, in time of economic downturn the Banks should not cut their budgets for Advertising \& Promotion and they should concentrate more on communication image campaigns instead of promotional activities and special offers.

According to the data from the marketing agency Publicis, is interesting to see that in the first four months of 2009, the budget that is spent for advertising \& promotion is increased when compared with the same period in the previous two years, 2007 and 2008. For example the total spending of the banks for A\&P activities form January till April 2008 compared to the same period 2007 is increased for $11.07 \%$. Also the total spending for advertising and promotion activities the same period (January - April) 2009 compared to 2008 is increased for $39.61 \%$ and for $46.30 \%$ compared to 2007.

According to the data for the total spending of the Financial Institutions Banks for Advertising \& Promotion activities, following are data divided in few types according to the spending per:

- Types of products

○ Months

0

As we can see in the next few charts, it is very interesting to see that the banks in the year 2007 most of their budgets spent for credit cards, corporate campaigns, or business loans. In the year 2007 there is no spending for deposits from any Bank.

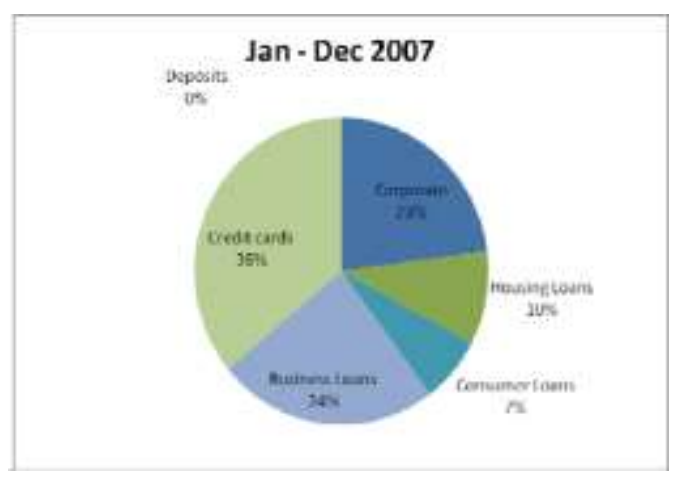


Source: Spending per type of product Jan - Dec 2007, Internal report from Publicis for Stopanska banka AD - Skopje

In the year 2008, the largest par of the pie belongs to the deposits, $30 \%$ of the total spending for Advertising \& Promotion. The spending for corporate campaing and credit cards still remains as important part of the total spending, the spending for housing loan is considerable increased, but the spending for business loans is considerable decreased.

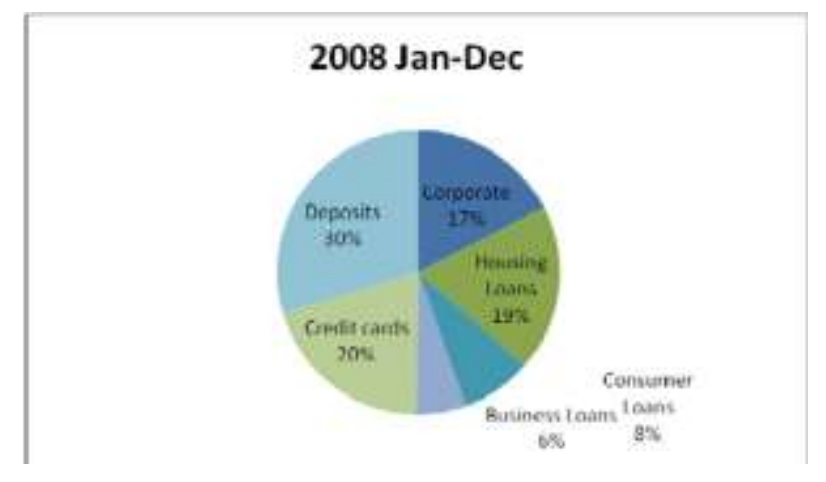

Source: Spending per type of product Jan - Dec 2008, Internal report from Publicis for Stopanska banka AD - Skopje

When comparing only the period from January untill December in three different years, we can see that in 2007 the concentration is on the Credit cards, corporate campaigns and business loans again. In the year 2008 the concentration at that period remains on the deposits, housing loans, credit cards, and lower spending on corporate campaigns.

In the year 2009 we can see that $90 \%$ of the total spending is divided between two types of products - deposits $38 \%$ and credit cards $52 \%$. But it is very important to highlight that the total spending for credit cards of $52 \%$ is done only by one bank - Komercijana Bank, because of the intensive and agresive campaign for Visa credit card winning game during the four months (form January untill December). 




Source: Spending per type of product Jan - Apr 2009, Internal report from Publicis for Stopanska banka AD - Skopje

When the analysis is made according to the spending per Bank the following conclusions are appearing: Stopanska bank is constantly the biggest spender in advertising \& promotion. Usually the followers are Tutunska bank, Komercijalna bank and IK bank. These four banks represent $3 / 4$ of the total spending on the market, so $1 / 4$ of the market is divided between other smaller banks.

The spending per months in the following chart shows common movements when comparing 2007 and 2008. Usually at the beginning of the year the spending is lower and it increases gradually. Than in the summer it decreased especially in August. After the summer the spending from September is constantly increasing untill the end of the year.

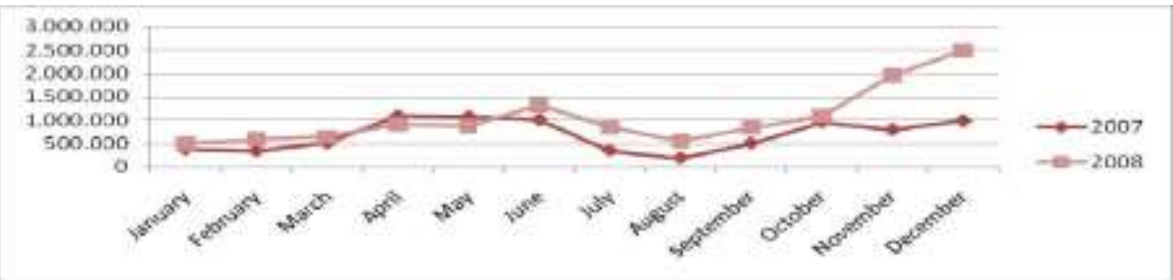

Source: Spending per months Jan - Dec 2007 \& 2008, Internal report from Publicis for Stopanska banka AD - Skopje 


\section{Macedonian leasing market}

Macedonian leasing market is still evaluated as underdeveloped in comparison with regional countries. However, during 2007 and 2008 the Macedonian leasing market grew up remarkably in comparison with previous years:
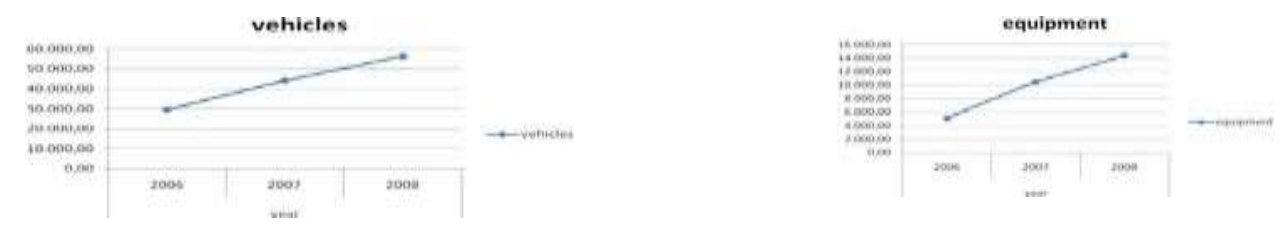

Source: Central register of Republic of Macedonia, 31.12.2008

The enclosed charts are presenting the dynamic of leasing market development in Macedonia within the past 3 years: 2006, 2007 and 2008, segmented by product type (vehicles and equipment leasing).

The leasing market is composed of 4 leasing companies:

1. Hypo Alpe-Adria-Leasing DOOEL Skopje

2. NLB Leasing

3. Porsche Leasing

4. Euroleasing

Hypo Alpe-Adria-Leasing DOOEL Skopje and NLB Leasing are carrying the dominant market share:

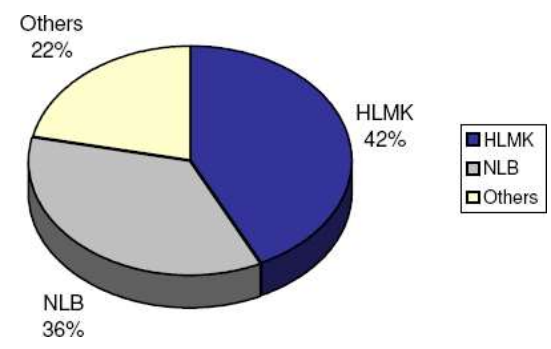

Source: Central register of R. Macedonia 31.03.2009 
Remarkable changes in marketing strategies and product development occurred. New financial or slightly modified products are launched in accordance with the new business policy of the banks and leasing companies. The promotional and advertising activities were centered on deposits and mortgage loans, and less on consumer uncollateralized loans. However, in the start of 2009, significant volume decrease was registered in terms of leasing financing as well.

Leasing Market 1st Q 2009 vs. 1st Q 2008

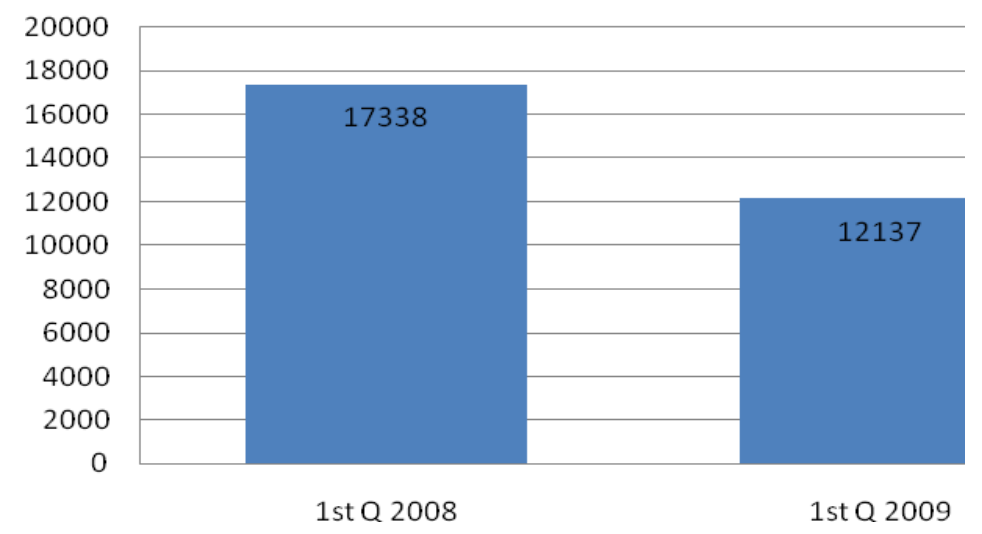

Source: Central Register of R. Macedonia, as of 31.03.2009

The leasing segment, in 2008 was recognized as the most dynamic component of the financial market. In 2009, the development of leasing segment was slowed down, (30\% decline) in parallel direction with leasing companies advertizing activities. Almost no marketing activities were done by any leasing company on the market, which resulted into decreased trustworthy by the market and decreased sales.

Taking this into account and detecting that one of the most concerned segment is the export oriented companies and industrial production SME's, one of the most dominant leasing company on Macedonian market changed its product development plan by launching new product "Business leasing" targeting the SME's which have the most jeopardized liquidity. 


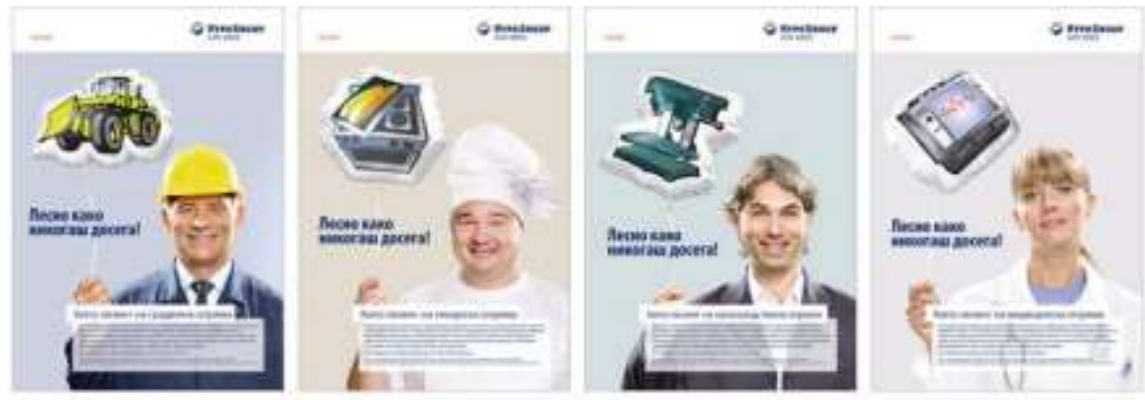

Pictures 2: Business leasing advertising campaign of Hypo Alpe

Adria

One of the most powerful elements of marketing communication during economic downturn is the PR. The direct addressing of the top management during economic and financial uncertainty can be seen as the closest, imminent and most powerful formula for obtaining the image and market position.

In times when there are rapid changes in the business models, strict monitoring of the payment behavior, followed by dramatically cost cutting policy and lowering marketing budgets, leasing companies are facing enormous challenge when making decisions what message should be sent to the market, how to communicate the message and when.

\section{Results from the marketing communications at financial institutions}

During the current crisis the marketing communication is mostly realized through the Banks' Advertising. Only few banks are using sales promotions as wining games for credit cards. PR activities are also present by most of the financial institutions, influencing on the credibility and the corporate image perception, even though with small budgets but with very good effects. Direct marketing is rarely used, which is an issue because of old banks' databases and not using the unique opportunity. This should be changed in the near future, if the financial institutions wants better results. As we seen before, from the Advertising agency media analyses, some banks continued with the advertising during the last financial crises and some of them cut the advertising budget completely. There are different strategies regarding this question, especially according to the type of the product. However the research is showing different results for the banks using and not using advertising activities in this period. 
According to the internal data and analysis of Stopanska banka AD - Skopje, that are provided with this research we can see that during the period of the crisis the advertising remains to be considered as very important in order to maintain the image of a safe bank with long tradition and with great knowledge and experience. The concentration during this period of crisis is deposit campaigns and image campaigns, compared to the previous period when the concentration was mostly on lending products. Even now lending product's campaign is mainly image campaign without any promotional offer. The results are showing maintenance of the lending products' sales with an objective to grow after the crisis are finished.

Regarding the long-term results those banks, which are using advertising, are repositioning on the market and taking bigger market share. I.e. Stopanska banka AD - Skopje is showing increase in the mortgage loan market share during the months while the marketing campaign is active. Although almost $40 \%$ of the market belongs to Stopanska banka, the market share is constantly growing for approximately 0.2 percentage points every month.

According to the table bellow we can see that the interest for Housing loan is highest during the period when the advertising campaign was active with special offer for the clients, i.e. from May - October 2008. In 2009 was performed image campaign for Housing Loan, during February and March, with aim to maintain constant growth in the portfolio of $1-2 \%$ compared with the previous month.

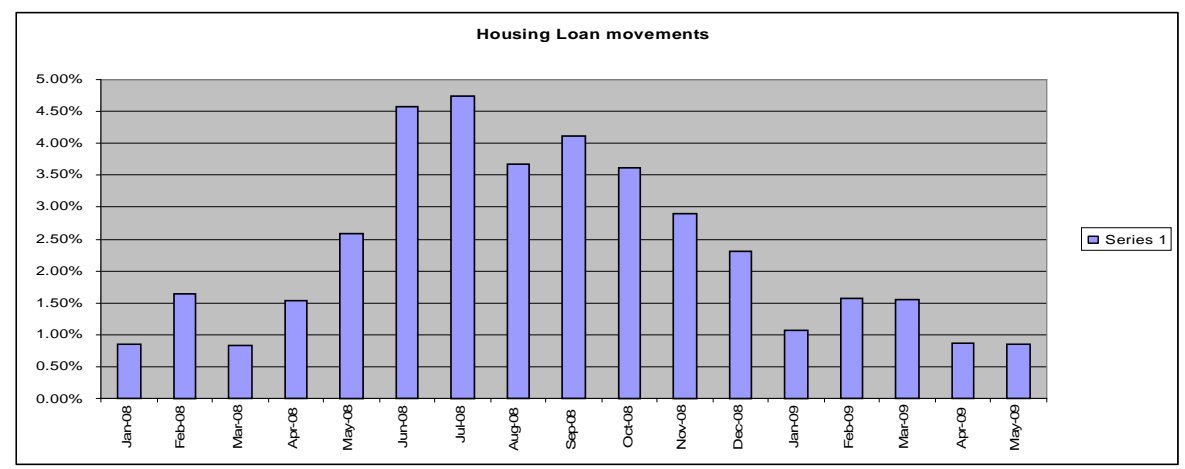

Source: Housing Loan movements, Internal report of Stopanska Banka AD - Skopje, May 2009

Accordingly the amount and the number of deposits are increasing during this period in parallel with the increased advertising for deposits. The 
market share of Stopanska banka is constantly growing in the field of deposits. Every month it is noticed growth of 0.2 percentage points.

Stopanska banka has started with advertising activities for deposits from September 2008, and by now is constantly active. As we can see in the chart bellow, the growth for deposits is bigger before the crisis.

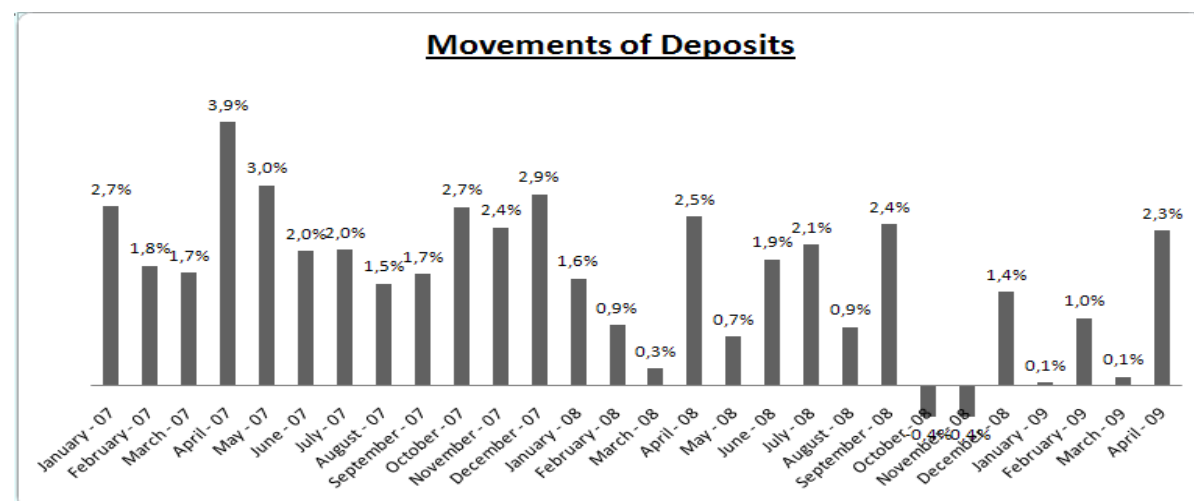

Source: Movements of deposits, Internal report of Stopanska Banka AD - Skopje, May 2009

It is obvious that the crisis are influencing on the customer perception of safety of the Banks, as few banks has bankrupt in the World and therefore less people are willing to deposit their money in the banks. At the end of 2008 there is a decrease in the deposit growth, as a consequence of the World crisis. During the crisis advertising is actually assisting in keeping the brand and corporate image, stressing the safety of the Banks with an objective to maintain the constant level of clients and growth in the market share.

According to the chart bellow, also we can see that the portfolio of unsecured loans is constantly decreasing, starting October 2008 along with the crisis. The main reason is because the banks are interested in offering secured loans, the credit criteria for unsecured loans are strengthened and the bank stopped all advertising activities for this type of products after the crisis started. 


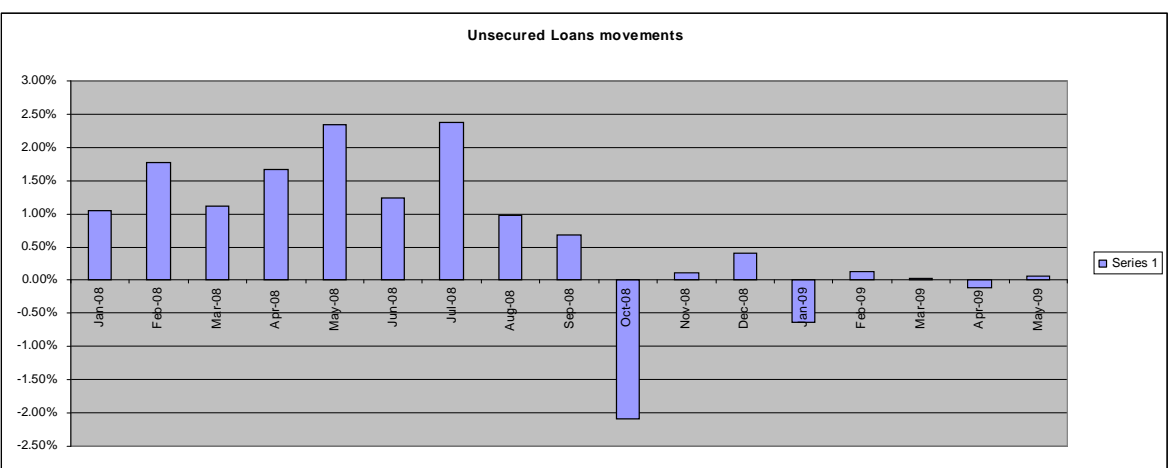

Source: Unsecured Loans movements, Internal report of Stopanska Banka AD - Skopje, May 2009

Almost no marketing activities were done by any leasing company on the market, which resulted into decreased trustworthy by the market and decreased sales, as written in the previous part.

We cannot assume what will happen after this crisis finish, but the previous advertising experience is showing better results for the Banks, which were active with marketing communication during the crisis period, with effects on strengthening Banks image and market positioning.

\section{Conclusion}

Taking into account the unique features of the current crisis and its implications on the marketing strategy and budgets, the obvious conclusion is that the marketing communication strategy should be centered on four major components:

+ Promotion of new or modification of existing products in accordance with the external conditions and internal business strategy

+ Deliberate and neat PR activities on continual basis: regular PR Interviews and media events should take place in order to inform the public about company's business and stability. PR activities are less expensive but much more powerful tool that should be wisely used during economic uncertainty. Being silent is also communication, but negative one. 
+ Corporate and brand building advertising campaigns, with awareness and brand image maintain purpose.

+ Staff training and motivation, as they have largest impact on the customers' financial institution choice.

Out of this conclusion we can extract a short guidelines, which can serve as a lesson for future challenges:

X Select refining target audience

+ During economic downturn, when costs are "big issue" and marketing budgets are lowered, the advertising activities should be directed toward customers who will bring profits. Business objectives should remain ground basis for developing marketing strategies;

X Innovation is a key to success

+ Implications for marketers: differentiate trough innovation with product or service that performs in faltering economy; invest in R\&D now to ensure that your company is in a position to compete when the economy rebounds.

$x$ Continue researching

+ Implications for marketers: Conduct research to understand your competitor position and your target audience perception of the economic environment; hone and refine your messages; highlight the value of products and services, rather than slashing the price.

X Sustain the brand

+ Corporate brand campaigns are needed in order to obtain the market position and the image of the company.

\section{References:}

Pacek N \& Thorniley D (2004). Emerging markets. Lessons for business success and outlook for different markets. The Economist. $115-128$

Ogilvy D (1985). Ogilvy on advertising. First Vintage Books Edition. 167 - 172

Ennew C., Watkins T. \& Wright M. (1995) Marketing Financial Services. ButterworthHeinemann,

DiMassimo, M. (2001) Advertising in Crisis: A 20th Century Tale. Brandweek. Vol. 42 Issue 37, $\mathrm{p} 46,1 \mathrm{p}$

Iverson, B. (2008) Banks, for Your Own Good, Fill The Silence. American Banker. Vol. 173 Issue 201, p12-12, 1/2p 
Schifferes S. (2007) Financial crises: Lessons from history. Analysis. Economics reporter, $B B C$ News

Wikipedia Dictionary, Recession, Retrieved from: http://en.wikipedia.org/wiki/Recession (Accessed 22 May 2009)

Wikipedia Dictionary, Financial_crisis, Retrieved from: http://en.wikipedia.org/wiki/Financial crisis of 2007\%E2\%80\%932009 (Accessed 22 May 2009)

Wikipedia Dictionary, The Keynesian Resurgence, Retrieved from: http://en.wikipedia.org/wiki/The Keynesian Resurgence of 2008 / 2009 (Accessed 22 May 2009)

NBRM, Quarterly Report January 2009, Retrieved from: http://www.nbrm.gov.mk/WBStorage/Files/Quarterly Report January 2009.pdf (Accessed 22 May 2009)

NBRM, Quarterly Report April 2009, Retrieved from: http://www.nbrm.gov.mk/WBStorage/Files/Kvartalen\%20izvestaj_april 2009 3.p df (Accessed 22 May 2009)

NBRM, Monthly Report February 2009, Retrieved from: http://www.nbrm.gov.mk/WBStorage/Files/Monthly Report 02 2009.pdf (Accessed 22 May 2009)

NBRM, Public relationss, press release, 25 December 2008, Retrieved from: http://www.nbrm.gov.mk/defaulten.asp?!temID=8EBD2C0DA8921949BF4218FA4499D8A8 (Accessed 22 May 2009)

NBRM, Treasury Bills, Retrieved from: http://www.nbrm.gov.mk/default-MK.asp (Accessed 26 May 2009)

Market research performed by IMAS International; Client: Hypo Bank International, January \& February 2009

Euribor rates, Retrieved from: www.euribor-rates.eu, (Accessed May 2009) 